Article

\title{
Fluid Waters and Rigid Livelihoods in the Okavango Delta of Botswana
}

\author{
Brian King ${ }^{1, *}$, Jamie E. Shinn ${ }^{2}$, Kelley A. Crews ${ }^{3}$ and Kenneth R. Young ${ }^{3}$ \\ 1 Department of Geography, The Pennsylvania State University, University Park, PA 16802, USA \\ 2 Department of Geography, Texas A\&M University, College Station, TX 77843, USA; jamieshinn@tamu.edu \\ 3 Department of Geography and the Environment, University of Texas at Austin, Austin, TX 78712, USA; \\ kelley@utexas.edu (K.A.C.); kryoung@austin.utexas.edu (K.R.Y.) \\ * Correspondence: king@psu.edu; Tel.: +1-814-865-1628; Fax: +1-814-863-7943
}

Academic Editors: Claudia A. Radel and Jacqueline M. Vadjunec

Received: 17 August 2015; Accepted: 31 May 2016; Published: 11 June 2016

\begin{abstract}
Current and future impacts of climate change include increasing variability in a number of biophysical processes, such as temperature, precipitation, and flooding. The Intergovernmental Panel on Climate Change (IPCC) has suggested that Southern Africa is particularly vulnerable to the anticipated impacts from global climate change and that social and ecological systems in the region will be disrupted and likely transformed in future decades. This article engages with current research within geography and cognate disciplines on the possibilities for responsive livelihoods within socio-ecological systems experiencing biophysical change. The paper draws from an ongoing research project that is evaluating perceptions of environmental change, specifically of precipitation and flooding dynamics, in order to understand social responses. We report on the findings from qualitative interviewing conducted in 2010 and 2011 in the communities of Etsha 1, Etsha 6, and Etsha 13 within the Okavango Delta of Botswana. While flooding and precipitation patterns have been dynamic and spatially differentiated, some livelihood systems have proven rigid in their capacity to enable adaptive responses. We assert this demonstrates the need for detailed research on livelihood dynamics to support adjustments to biophysical variability within socio-ecological systems experiencing change.
\end{abstract}

Keywords: climate change adaptation; livelihood; governance; socio-ecological system; Botswana

\section{Introduction}

The Fourth Assessment Report of the Intergovernmental Panel on Climate Change (IPCC) (AR4) detailed current and future impacts of climate change, including increasing variability in a number of biophysical processes, specifically temperature, precipitation, and flooding $[1,2]$. The recently released Fifth Assessment Report (AR5) of the IPCC confirms these findings, with added confidence in the likelihood of climate-driven disruptions to human and environment systems [2]. Working Group II of the IPCC has projected that Southern Africa is one of several areas particularly vulnerable to global climate change and that livelihood systems in the region will likely be disrupted and transformed in future decades [3]. The predictive models for Southern Africa are not uniform in their assessments of these changes, with some studies predicting wetter seasons while others anticipate drier months than those at the present time [4]. While the implications for institutional systems and livelihood decision-making are stark, research has been limited in addressing the specific factors shaping perceptions of environmental variability and potential for effective responses. A key factor is the governance regime, which involves the individuals, organizations, rules, and traditions that help shape environmental perceptions and livelihood responses. Yet the specific relationships between livelihoods and governance regimes are not well understood, particularly within settings experiencing 
socio-environmental variability. This complicates the possibilities for adaptive responses that are sensitive to local context and sustainable in the face of future perturbations.

This article engages with current research on climate change adaptation while focusing upon the possibilities for responsive livelihoods within socio-ecological systems experiencing biophysical change $[5,6]$. We begin with a review of some of the recent scholarship on environmental perceptions and environmental governance. This is followed by a discussion of the case study and methodology, which relied upon semi-structured interviewing and livelihood mapping conducted in May 2010 and from May to June 2011. The paper reports findings from an ongoing research project in the Okavango Delta of Botswana that is evaluating perceptions of environmental change, specifically of precipitation and flooding dynamics, in order to understand livelihood responses to variability. The timing of this research is particularly opportune because the study region experienced annual flooding from 2009 to 2012 that was higher than the previous decade. The geomorphological interactions of the Okavango Delta's landscape features and spatio-temporally variable flooding dynamics have produced intra-regional and intra-village impacts including the permanent displacement of residents within the study area. We find that while environmental perceptions vary within the region, adjustments to biophysical variability remain tied to livelihood systems that can constrain adaptive responses. We conclude by suggesting that this research helps demonstrate the need for future research on climate change adaptation within the natural and social sciences.

\section{Environmental Perceptions and Governing for Adaptation}

The ways in which human populations understand and adjust to environmental variability has been a topic of interest within geography and other social science disciplines for decades. Environmental dynamics can be variable and unpredictable, and generate local perceptions that influence decision-making in multifaceted ways. For example, drylands have precipitation regimes that are both temporally and spatially variable. Agriculturalists living in these types of variable environments must make decisions based on a level of uncertainty and risk, including assessing when, where, and which crop varieties to plant during a growing season. As climate change leads to greater variability in the drivers of agrarian systems, agriculturalists will need to make decisions amidst higher levels of uncertainty. Other livelihood practices, such as livestock management and natural resource collection, are similarly impacted by dynamic environmental change. People perceive risk through an integration of analytical and experiential processing systems [7,8]. Marx et al. [8] argue that where most communication about climate risk assumes people process information analytically, there is a need for greater attention to the role of experiential processing in how people perceive risk. In turn, an expanded focus on experiential processing recognizes that decision-making is in part based on a person's or group's past experiences of similar situations, including the emotions (positive and negative) associated with those experiences. To this end, there is an existing body of work focused on how to foster more effective communication between climate scientists and local populations living in variable environments [8-10].

A larger body of case-study specific work mainly focusing on precipitation patterns considers the differences between meteorological data and environmental perceptions. Some studies reveal at least some congruency between environmental perceptions and scientific interpretations of rainfall patterns [11,12]. However, a larger number of studies detail inconsistencies between perceptions and regional climate data $[9,13,14]$. Importantly, many of these studies reveal that inconsistencies are not the result of "incorrect" interpretation, but rather result from these groups paying attention to different variables in terms of rainfall and its impacts. For example, a number of studies have shown that while agriculturalists are concerned with the timing of rain (e.g., how well precipitation aligns with a growing season), scientists tend to be concerned with the overall quantity of rain in a given time period (e.g., a year) (examples include $[9,11,12,14]$ ). Further, some studies suggest that it is not just the quantity and quality of rainfall that impacts environmental perceptions, but also a set of social and ecological variables in a given context [13-15]. Meze-Hausken ([14]; p. 30) noted that 
"peoples' perceptions about climate are in fact a combination of various environmental aspects ... any analysis of subjective observations about weather and climate requires a deeper investigation of the socioeconomic, cultural and environmental conditions experienced by the affected people." Taken together, these studies show that perceptions of environmental variability are likely the result not only of current experiences, but result from complicated socio-environmental relationships that are rooted in historical experiences with biophysical variability.

Understanding perceptions of environmental change has proven important "at a time when biophysical and social environmental conditions are seen as increasingly volatile, unpredictable, uncontrollable, and interconnected" ([16]; p. 616). The possibilities for climate change adaptation exist within decision-making processes that extend across multiple spatial and temporal scales. While environmental governance has been a unifying theme for a variety of academic disciplines and research fields, there are divergent understandings of what this concept actually entails. One useful conceptualization is of the governance regime, which is understood as the collections of institutions and stakeholders operating across spatial and temporal scales that intersect in making the decisions of how environmental systems are perceived and managed. Governance systems include the individuals, organizations, rules, and traditions that help shape how decisions are made, power is exercised or resisted, and commitment to collective objectives achieved [5,17-20]. The governance systems under particular frames of study are themselves embedded within political and economic relationships that make them vulnerable to perturbations or stresses. The increase in scholarship on resilience or adaptive governance systems [21] reflects the concern that some of these systems are not well positioned to respond to environmental change [22]. For example, in some of this work global climate change and associated weather-related hazards are presented not as problems with the natural resource base but as "governance failures" ([23]; p. 354). Under circumstances of social and ecological fluctuation and change, the governance regimes therefore prove critical in providing flexibility for livelihoods to respond to changing circumstances, while offering resources and capacity building to anticipate and respond to future pressures.

While environmental variability, environmental perception, governance, and livelihood production are central to the adaptive capacity of individuals and households in the Global South, more research is needed to provide explicit empirical detail as to their relationships. This is particularly important within contexts that are experiencing environmental change, to identify the specific ways in which environmental variability is understood, in addition to whether livelihood systems can support adaptive responses. As detailed in the next section, the Okavango Delta of Botswana is characterized by variability in precipitation and flooding dynamics that necessitate dynamic responses at multiple decision-making scales. As such, it is a unique setting for examining the relationships between livelihood systems and biophysical variability.

\section{Case Study and Methodology}

The Okavango Delta is not actually a delta but is an inland alluvial fan stemming from the panhandle into the distal portions. This wetland system is notable for its location within a savanna system in the Kalahari Desert, with its waters being fed by local precipitation and upstream precipitation in the Angolan highlands. The relative contribution and amounts of these two inputs vary temporally and are thought to respond to the shifting of the Southern Atlantic Oscillation (SAO) [24]. The Delta is characterized by high spatial and temporal variability with regards to both precipitation and flooding. Water levels in the fan vary considerably seasonally and spatially each year, covering anywhere from 8000 to $12,000 \mathrm{~km}^{2}$ [24]. The floods arrive into the distal reaches of the Delta an average of four months after the peak of the local dry season (winter) and after the local rainy season $[4,25]$. The Okavango Delta is additionally characterized not only by strong seasonal cycles, but also by longer term (interannual and quasi-decadal) variability [26], meaning that sites within the Delta may experience high and differential variability in proximity to, amount of, and timing of the arrival of the water [27]. 
The Delta is comprised of permanent, seasonal, and occasional swamps that flood typically every 2-3 years [28]. The fluvial geomorphological processes of this system move sand such that some rechannelization occurs in the fan portion of the Delta, which at times is unpredictable [29]. The Delta is comprised of interspersed wetlands, grasslands, savanna and woodland, including riparian, interfluves. As such it offers not only a variety of habitats and resources but serves as a source of water for both wildlife and anthropogenic uses, creating a complex and shifting socio-ecological system driven by irregular annual flooding. The Okavango Delta was declared a wetland of international importance in 1996 by the Ramsar Treaty (site \#879) and is globally significant as one of the world's largest wetlands. Land use in the region traditionally ranges from open access communal areas with subsistence agriculture and some livestock husbandry, to hunting and photography tourism concessions, game reserves and national parks, as well as settlements and villages along the periphery of the Delta. A recent and controversial national ban on wildlife hunting was implemented in January 2014 and is altering the assignment and use of a number of concession areas. The diverse management zones of the Delta are loosely controlled through veterinary fences and staffed checkpoints established by the national government intended to regulate the movement of animals and humans, in large part a response to earlier wildlife-cattle disease transmission. An outbreak of contagious bovine pleuropneumonia (CBPP), also known as cattle lung disease, occurred in the region in 1996, leading to the eradication of all cattle in Ngamiland in northern Botswana. In lieu of cattle killed, the Government of Botswana offered residents the option of replacement cattle or a cash reimbursement.

The Okavango Delta is one of Botswana's leading economic sectors, with tourism serving as one of the country's top three industries along with the cattle industry and mining. Many different ethnicities occupy the region including the long-term resident Bayei and Basarwa, with more recent immigrants from outside the country including Hambukushu, Herero and many Tswana-descended tribes. The study region for this project is predominately occupied by Hambukushu people, who were refugees from Angola during the country's civil conflict in the early 1970s, along with a small Bayei population, who moved to the villages after the Hambukushu settled there. The Delta is also a major source of resource extraction for local communities living on its periphery. The population of the Ngamiland West District, including the Etsha villages where this research was completed, is estimated at 64,864 [30]. There is a total of 175,631 people living in the entire North-West District, which encompasses the entire Delta and other areas of Northwestern Botswana. As detailed in the next section, it is well established that many residents of the Okavango Delta depend upon a diversified set of natural resource-based livelihoods [31-33], and that many of these livelihoods depend upon the precipitation or flooding patterns of the Delta [34].

This paper reports on research conducted in May 2010 and from May to June 2011 in the northwest of Botswana in the Okavango Delta (Figure 1). Semi-structured interviews were conducted along a twenty kilometer transect in the villages of Etsha 1, Etsha 6, and Etsha 13 (see Figure 1). A total of 82 semi-structured household interviews were conducted with 18 interviews in Etsha 1, 37 interviews in Etsha 6, and 27 interviews in Etsha 13. The number of interviews was conducted to reflect the different population sizes of the villages, and respondents were selected randomly using a spatially stratified sampling procedure that was designed to ensure geographic representation from the village. The increase in flooding caused differential impacts within the region, particularly within Etsha 13, where some village residents were displaced due to the floods. In order to understand these dynamics, seven of the Etsha 13 interviews were intentionally targeted. Semi-structured interviews of households were undertaken by the authors in English, Setswana, and Hambukushu with assistance from local interpreters. Interviews concentrated upon household demographics and history, use of natural resources and collection strategies, and perceptions of environmental variability within the area. Additionally, interviews probed individual and household perceptions of how variations in flooding and precipitation impact the collection and availability of natural resources. Text-based analysis of the interviews was conducted to identify themes related to environmental change and livelihood practices. These semi-structured interviews were complemented with three livelihood mapping 
exercises with select informants from each of the villages that provided spatially explicit detail on the location of livelihood practices and ways in which environmental change intersects with and reworks them. The mapping exercises included participant observation of resource collection and farming practices, the identification of key natural resource zones, and Global Positioning System (GPS) point collection for spatial analysis. This method was intended to build upon recent research intent upon spatializing livelihood systems to examine the ways in which livelihood systems and spatial processes are interlinked and co-produced [35].

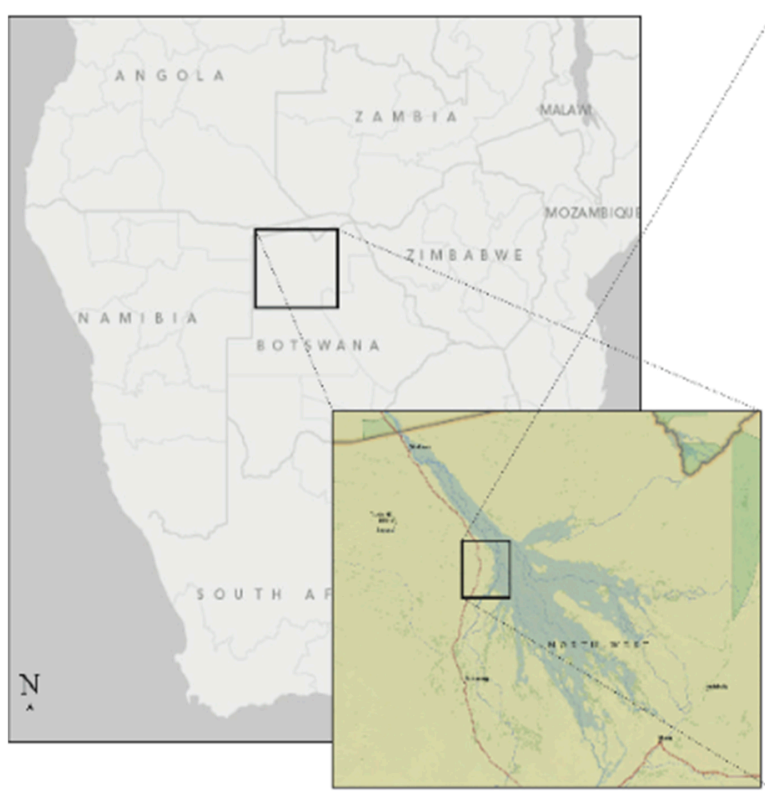

(a) Study area reference

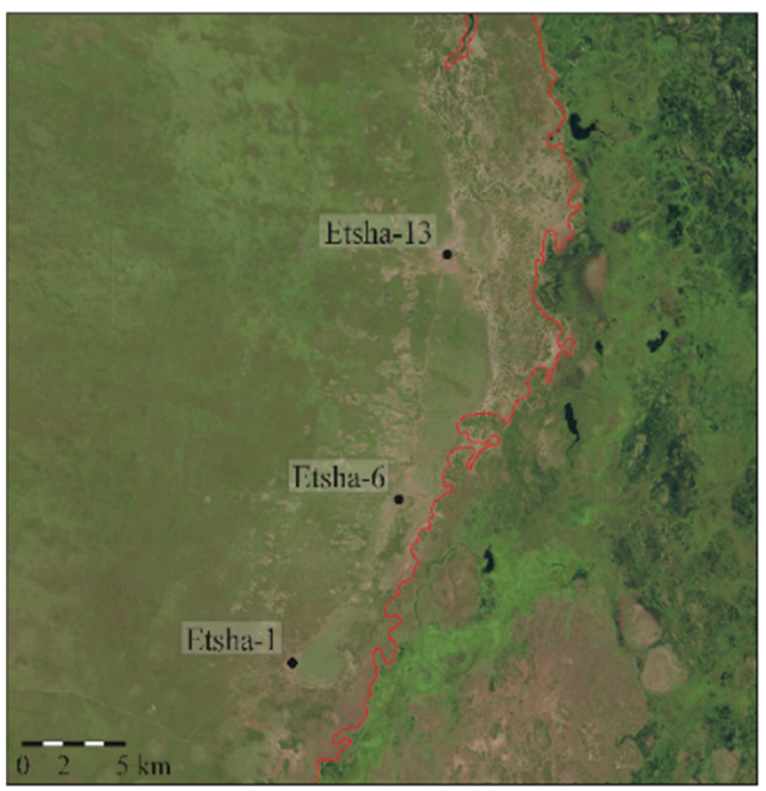

(c) May. 2006 flooding extent

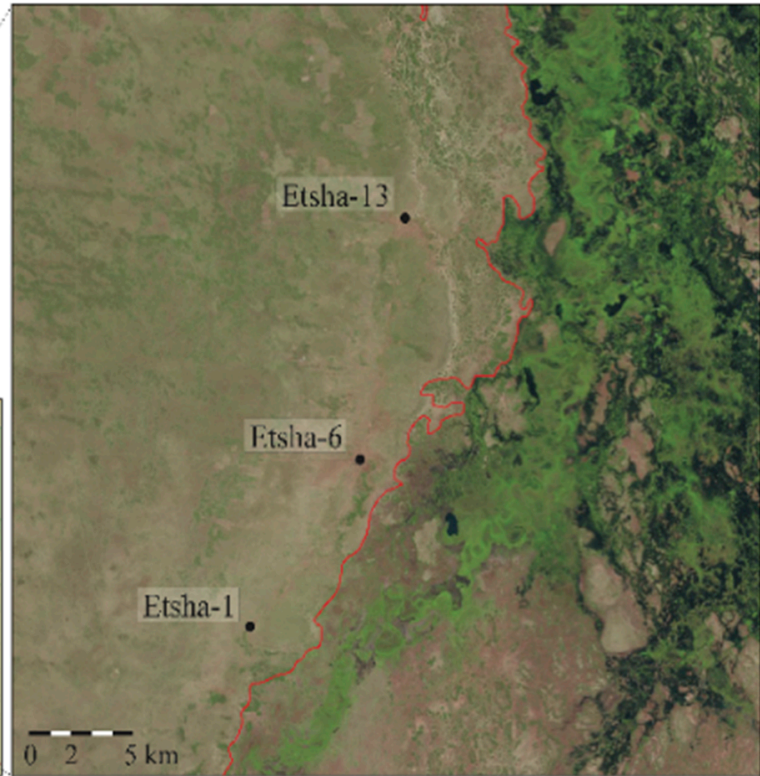

(b) May, 1998 flooding extent

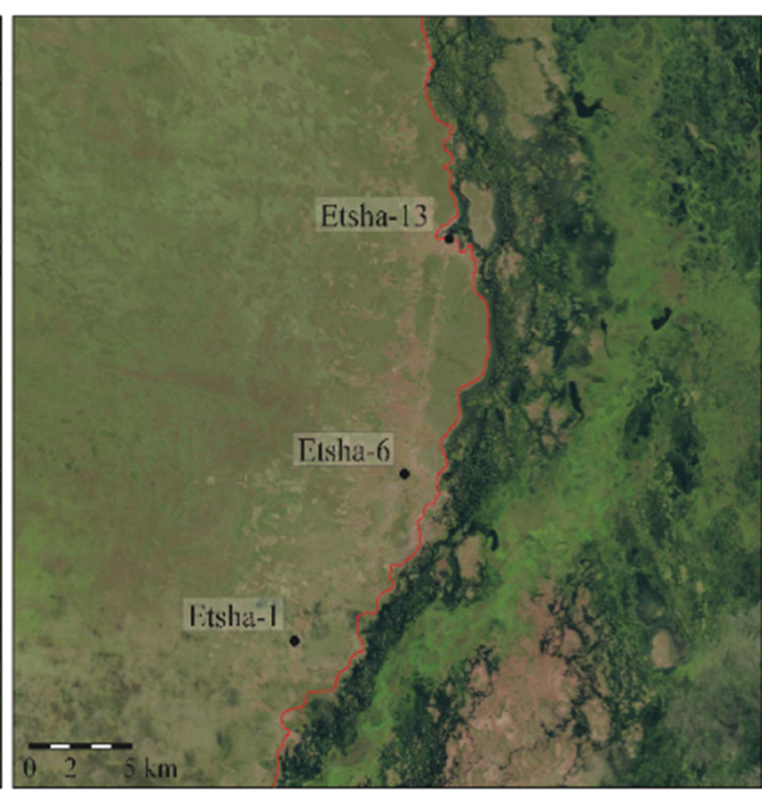

(d) May. 2010 flooding extent

Figure 1. Map of the study region with the variance in the spatial location of flooding indicated by the red line along the edge of the floodwaters. (a) Study area reference; (b) May, 1998 flooding extent; (c) May, 2006 flooding extent; (d) May, 2010 flooding extent.

In order to understand the institutional context shaping livelihood systems, semi-structured interviews were conducted with tribal authority officials, including the village chiefs, and 
governmental representatives from the Department of Wildlife and National Parks and the Tawana Land Board. These interviews concentrated upon the rules governing resource access in the region and how they are enforced. Similarly, the household semi-structured interviews asked detailed questions about not only the spatiality of natural resource collection, but also the rules shaping access regimes and the institutions responsible for administering them. These interviews concentrated upon the four key elements of environmental governance as identified by Pahl-Wostl (2009), particularly the role of formal and informal institutions, interactions between state and non-state actors, administrative boundaries, and bureaucratic hierarchies. As detailed in the next section, livelihoods are shaped by dynamic ecological systems, thereby challenging institutions to be responsive in ways that support livelihood systems while reducing vulnerability to future change.

\section{Livelihoods in the Okavango Delta}

Given the dynamic environmental conditions of the Okavango Delta, livelihood systems are either tightly calibrated to these biophysical dynamics or forced to make adjustments in response to biophysical variability [36]. One study of five villages located throughout the Delta found that households participate in an average of three livelihood activities [33]. One agricultural practice in the region is molapo (floodplain) farming (Figure 2), which is a traditional form of agriculture dating back at least several hundred years and that takes advantage of the unique flooding dynamics of the Delta [37]. As the floodwaters recede at the end of the wet season (roughly around August-September, though this varies spatially and temporally), molapo farmers plant seeds in the relatively nutrient-rich, moist soil left behind by the waters [37]. Molapo soils are preferred by some residents to those in the dryland outside of the floodplain because they are seen as more fertile and they depend less on variable precipitation patterns because of their proximity to water. Maize, a staple grain in the region, is grown in nearly all molapo fields, along with beans, melons, squash, and sorghum [37]. There is risk associated with molapo farming due to crop loss resulting from years of high levels of flooding, insecure land tenure, and damage from livestock and wild animals. When damage to molapo fields occurs, residents in some regions switch to dryland farming, while people in other areas prefer to try to continue to molapo farm [34].

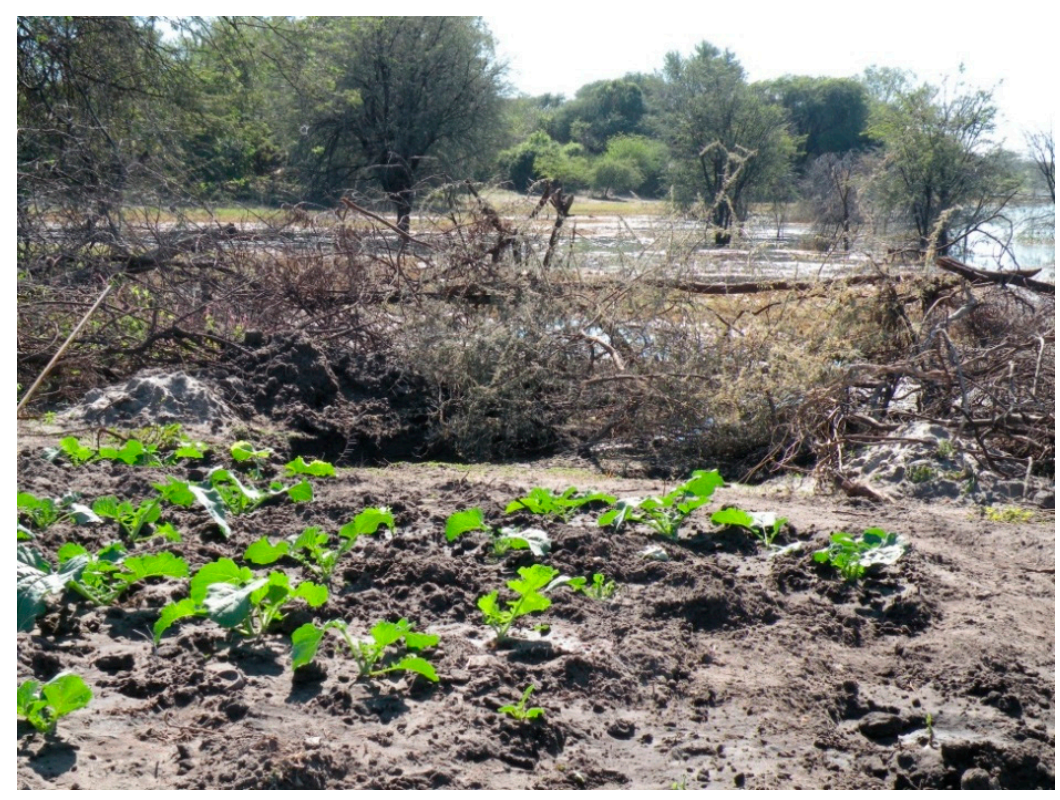

Figure 2. Molapo field in Etsha 1. Credit: Brian King.

Livestock husbandry is practiced throughout the Okavango Delta. Motsholapheko et al. [33] found that livestock husbandry was the most common livelihood practice in four of the villages. 
Another study in five different villages of the Okavango Delta (including Etsha 6, one of the study sites for this project) found that livestock husbandry was ranked as the third most common livelihood practice after arable farming and formal employment [34]. In one study, some households complained that increased flooding led to less pasture for their cattle when grazing areas were submerged in water for long periods of time [33]. Another study found that 33\% of residents in 22 villages surveyed use the Delta to water their livestock [34]. Thus, livestock husbandry is widely practiced in the region and has direct relationships with variable precipitation (and associated variability in groundwater depth and quality) and flooding patterns.

The collection of non-timber plant products is also integral to livelihoods in the Okavango Delta. These resources include reeds, thatch grass, palm, water lilies, and wild fruits [38]. Wild fruits are collected in both wetland and dryland areas; however, there is little information on their importance to household food security, or on the status of their availability. Water lilies are also collected as a food source, and it has been recently reported that they are not readily available due to both an increase in demand and shifting flooding dynamics [31]. Palms and grasses are used for fibers for basket weaving, which is a source of income for women in the region. Leaves and roots of various other species are used to create dyes for the baskets. Reeds and thatch grasses are also used in the construction of homes, roofs, and fences (Figure 3).

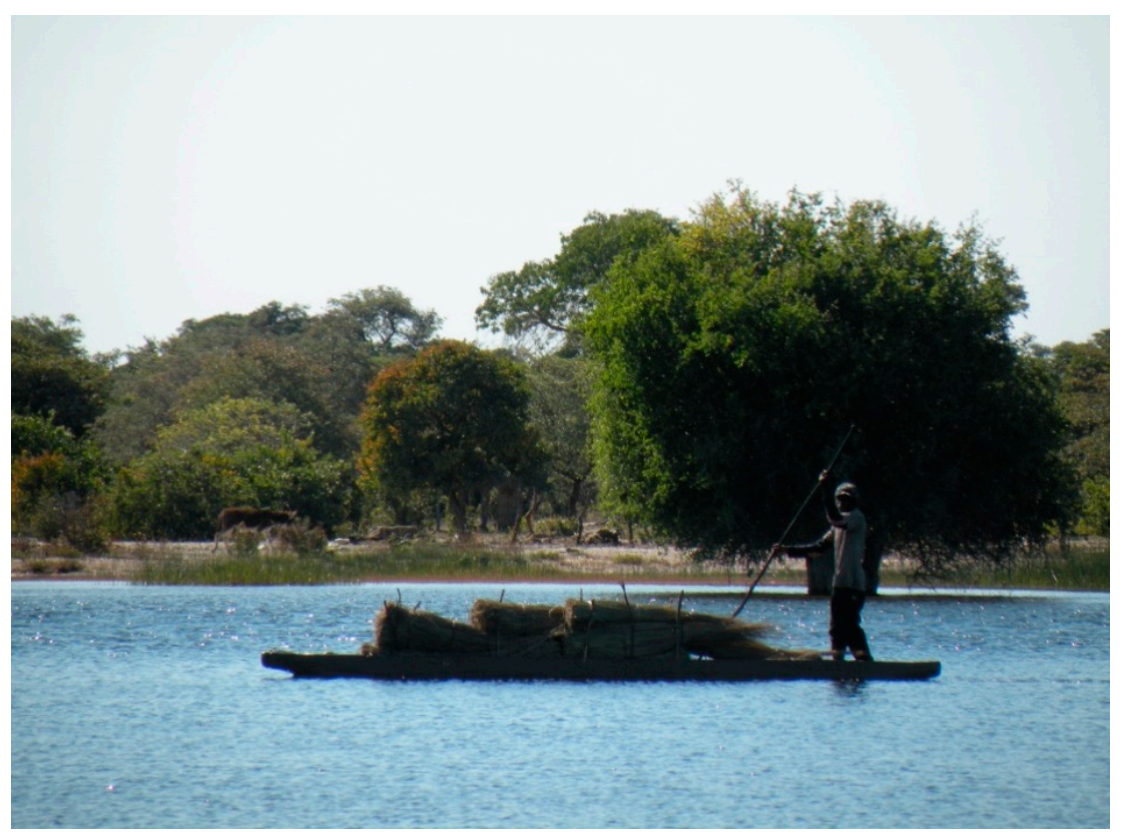

Figure 3. Transporting reeds by mokoro, a traditional dugout canoe, in Etsha 13. Credit: Brian King.

Lastly, fishing has been reported as a livelihood practice in the study region. One study found that $65 \%$ of the population of Northern Ngamiland depends on fishing as one source of food or for income generated from sale ([39], cited in [31]). However, a competing study found that fishing is less essential to local livelihoods [32]. Taken together, the collection and use of natural resources serves as a critical component to livelihood production within the Okavango Delta, including in the study region. What is particularly important to emphasize is that because this environmental setting is dynamic, the implications of changing precipitation and flooding for social systems can be significant for residents. This has proven to be the case in recent years with flooding in the study region reaching much higher levels than in the previous decade. Beginning in 2008, there was an expansion of floodwaters in the Delta that was driven by a number of factors. This continued in the years following, including the two years during which this research was conducted. Because much of the existing scholarship cited above was conducted prior to the onset of increased flooding in 2008, the research reported here was 
designed to evaluate how shifting aquatic ecologies are shaping perceptions of environmental change and resulting livelihood decision-making within the Okavango Delta.

\section{5. "We Do Not Understand How and When It Rains": Perceptions of Environmental Change in the Etshas}

Many of the households in the three villages engage in at least one form of subsistence agriculture, either in the form of molapo or dryland farming. Given this, people's lives are intimately tied to precipitation patterns, largely in the case of dryland farming, and to the floods, primarily in the case of molapo farming. Respondents in all three villages reported that precipitation has become increasingly variable over time. People did not always describe changes in rainfall in the same way, with some people reporting more rain in recent years, while some people reported less. However, the majority of respondents indicated that precipitation patterns were less predictable than in the past, with negative implications for their ability to grow crops. One respondent described these changes as a "new-fashion" kind of rain. Respondents often detailed that the rains now come in the "wrong" season when temperatures are high. Many interviewees described their dryland crops getting "scorched" in the sun, when the rain unexpectedly stopped for long periods of time. Some respondents also indicated that their crops rotted due to too much rain. For example, in Etsha 13, 30\% of these respondents mentioned that too much rain caused their crops to rot, whereas $37 \%$ mentioned precipitation changes causing their crops to get "scorched." Some respondents even discussed crops in the same field being scorched and then rotting in the same season. This indicates that at times there was more rain than expected, and at times there was less than expected, or simply no rain at all.

There were high percentages of people in all three villages who perceive changes in precipitation (Table 1), with most of the comments concerning the unpredictability of rainfall. One resident of Etsha 6 described how the unpredictability in precipitation impacted his household's ability to dryland farm in 2011, describing how first it rained, then it stopped and the crops wilted. After that, the family plowed a second time to replace the lost crops, but they had to settle upon a smaller area. Of particular note, $22 \%$ of respondents in Etsha 13 indicated that changes in precipitation were leading to food insecurity for their households, compared to $0 \%$ of respondents in Etsha 1 and $11 \%$ of respondents in Etsha 6. While precipitation data from this region is not available for comparison with local perceptions, precipitation gauges at the Maun airport, which is located roughly 200 kilometers southeast of the study region, show variability over the time periods of study [40]. These data should be interpreted with some caution because precipitation can be extremely localized; however, they support the patterns articulated by our respondents.

Table 1. Perceptions of changes in precipitation.

\begin{tabular}{lccc}
\hline & $\begin{array}{c}\text { Etsha 1 } \\
(\mathbf{n}=\mathbf{1 8})\end{array}$ & $\begin{array}{c}\text { Etsha 6 } \\
(\mathbf{n}=\mathbf{3 7})\end{array}$ & $\begin{array}{c}\text { Etsha 13 } \\
(\mathbf{n}=\mathbf{2 7})\end{array}$ \\
\hline \% of households reporting changes in precipitation & $88 \%$ & $97 \%$ & $81 \%$ \\
\% of households reporting unpredictable precipitation & $72 \%$ & $81 \%$ & $81 \%$ \\
\hline
\end{tabular}

While respondents in the three villages had somewhat similar perceptions of changes in precipitation, there was greater variation in views of flooding dynamics (Table 2). This can be interpreted as a function of each of the villages along the transect having a distinct spatial relationship with flooding, given their disparate proximity to the floodwaters. Etsha 1 is situated furthest from the floodwaters, with Etsha 6 slightly closer, and Etsha 13 located on the edge of the water during high flood seasons. Additionally, residents in Etsha 13 have built homes in the secondary floodplain thereby increasing vulnerability to flooding. This is not to say that residents of Etsha 1 have no relationship to changing flood patterns. As one resident said, "It is different than in the past. Water was not there at all and now it is everywhere." There was a general sense that the spatial distribution of water is changing near Etsha 1, but less discussion of direct impacts on the village, as compared to interviews conducted 
in the other two villages. Residents also talked about the flooding as something happening elsewhere, such as further away from their homes, than did village members in Etsha 6 or Etsha 13. Therefore, a key difference is that households in Etsha 1 were less likely to be directly impacted by flooding than households in Etsha 6 or Etsha 13. Distinct from Etsha 1, residents of Etsha 6 and Etsha 13 articulated a clear knowledge of spatial history of flooding near the village. Over half of the people interviewed in Etsha 6 mentioned that in the past, floods came directly to the village; $49 \%$ of those interviewed in Etsha 6 mentioned that water had risen closer to the village once again.

Table 2. Perceptions of changes in flooding and related livelihood impacts.

\begin{tabular}{lccc}
\hline & $\begin{array}{c}\text { Etsha 1 } \\
(\mathbf{n = 1 8})\end{array}$ & $\begin{array}{c}\text { Etsha 6 } \\
(\mathbf{n}=\mathbf{3 7})\end{array}$ & $\begin{array}{c}\text { Etsha 13 } \\
(\mathbf{n}=\mathbf{2 7})\end{array}$ \\
\hline \% of households reporting changes in flooding & $83 \%$ & $86 \%$ & $88 \%$ \\
\% of households reporting loss of molapo fields (complete or partial) & $50 \%$ & $35 \%$ & $59 \%$ \\
\% of households reporting increased difficulty in reed and grass collection & $44 \%$ & $45 \%$ & $66 \%$ \\
\hline
\end{tabular}

Residents perceive these changing flooding patterns as impacting livelihoods in the study area (Table 2). A high percentage of respondents in all three villages mentioned complete or partial loss of a molapo field, and commented about how reed and grass collection was getting more difficult due to higher waters. Some of these residents indicated that reed and grass collection would be made easier in the time of higher water if they had access to a mokoro (traditional canoe) to allow for harvesting. Other people indicated that they were able to collect reeds and grasses, but the season is later than in the past, because they have to wait for the water to go back down. One interviewee explained that if he waits for the water to go down before reeds are collected, it can be time to go back to the fields and he prefers to farm in the drylands rather than collect reeds because farming is their primary source of food. As the next section details, the seasonality of permitted collection of certain resources is one of the ways in which livelihood patterns are proving inflexible to biophysical change.

A number of findings on perceptions of environmental variability emerge from the semi-structured interviews in the study region. First, changes in precipitation and flooding are perceived as increasing the difficulty for subsistence agriculture in the three villages. Variability in precipitation is challenging dryland farming, and for households that depend on both dryland and molapo agriculture, there is a double impact from changes in flooding and precipitation variability. One respondent indicated that there is not as much food as in the past, because then they had plenty of rainfall and the water was closer and higher. A number of people expressed the view that floods will remain too high to practice molapo farming in the future, indicating a perception of permanent loss of this livelihood practice. However, many households mentioned that they would continue to farm, particularly in the dryland area, even if it yielded fewer crops in the future.

Second, results from this study indicate that residents experience increased difficulty in accessing reeds and grasses due to higher floodwaters near all three villages. This represents a livelihood challenge because of the importance of these materials for household construction and in the basket making industry, which is a lucrative source of income for some women in the region. Many people discussed higher waters leading to hazards during collection, either in the form of dangerous animals like crocodiles and hippopotamuses, or from drowning. As a result, a number of people mentioned the increased need for mekoros (plural of mokoro) to make collection easier. However, few families own mekoros, and they are difficult to build and expensive to purchase. Also of note, some interviewees indicated that one benefit of the higher floods is that once the water goes down and they can be collected, reeds and grasses are believed to be stronger than in the past.

Finally, this research speaks to important spatial relationships between community location and perceptions of environmental change. This is especially the case in Etsha 13, where many residents have been displaced from their homes and relocated to a dryland area, known as the New Stands, located a couple of kilometers from the village center [41]. In 2009, 2010, and 2011, floodwaters reached 
all the way to the village for the first time in recent decades. As a result, not only did many people lose molapo fields, but also some residents were flooded out of their homes entirely. While some people emphasized that life is better in the New Stands because they are out of the reach of future floods, others raised a number of concerns. Included was a lack of ability to build new homes (many residents were still living in government issued tents at the time of the interviews), lack of access to electricity, and further distances from standpipes, which are sources of potable water. Some people displaced by the floods previously possessed private standpipes and electricity connections but could not afford to install them in their new homes. Finally, some people simply preferred to live closer to the water and did not want to live in the dryland area. Therefore, while the relocation afforded some safety from floodwaters, it also posed a number of new difficulties for residents.

\section{Rigid Livelihoods within Dynamic Environmental Systems}

Patterns of biophysical change within the study region necessitate closer scrutiny to the decision-making processes that enable and constrain resource access and livelihood production for residents. There is a diversity of actors and institutions that contribute in shaping livelihood systems within the Etsha villages. At the national level, the Department of Wildlife and National Parks in the Ministry of Environment, Wildlife and Tourism sets rules for hunting of wildlife in the Delta and gives permits for fishing that specify seasons and the size and type of the nets that can be used. The Tawana Land Board is responsible for allocating plots of land for settlement and has been particularly active within Etsha 13 due to the displacement of residents from the floods and subsequent relocation efforts to the New Stands. Almost all land in the vicinity of the Etsha villages is considered communally owned tribal land, which is managed and allocated to citizens by the Tawana Land Board. Regional Land Boards in Botswana are part of the federal government system, as outlined in the Tribal Land Act of 1968. The Tawana Land Board provides 99-year leases on tribal lands to Botswana citizens for residential, arable, and borehole purposes. At the regional level in northern Botswana, there are officers working from the towns of Maun or Gumare who provide extension support to farmers or provide other types of development interventions. Within the villages themselves, traditional authorities, including local chiefs and headmen, adjudicate on local issues and, within the context of this study, provide guidelines on the location and timing of resource collection and molapo farming. The tribal authority office is based in Etsha 6, with the other villages having their own headmen that work within this institutional structure under the supervision of the chief. These governance institutions should not be interpreted as being fixed to particular locations; rather, they overlap and there is a flow of information and power among them. As such, residents must navigate multiple agencies in securing land or acquiring permission for specific forms of resource collection. For example, while the Land Board designates the dryland fields, residents noted that the chief provides the list of farmers and therefore is integral to the process of land allocation.

The institutional context is critical in either constraining or enabling livelihood flexibility to deal with variabilities in the biophysical system [22,23]. In the Etsha villages, local residents take their cues from a mix of traditional authorities, local governmental agencies, and regional or national agencies, as well as from cultural practices and biases, knowledge bases, and household and community histories. Different ethnic groups, whether Hambukushu or Bayei, evidence distinct livelihood practices that are tied to precipitation and flooding dynamics. As one informant from the village of Etsha 13 explained, "The Bayei prefer to plow at the river because our staple food is maize. When we arrived here the river was not flooded. It is getting smaller now because the flowing is changing, especially on the edges." The informal institutions that govern these landscapes can be localized to the particular molapo plot or floodplain island that supports seasonal fishing communities. Livelihood systems are therefore tightly calibrated to perceptions of environmental change on a monthly, seasonal, annual, and decadal scale. When asked about future preparations for precipitation, one resident from Etsha 13 stated: "We are not doing any preparation because the rain is a new rain. We do not understand how and when it rains. For next year, we might do the preparation and unfortunately the rain will come late." 
Another example of how livelihood systems are shaped by environmental change is through the variability in flooding patterns, which is reflected in the seasonality of natural resource collection. Residents explained that permits are needed for the collection of plant fibers for basket making, in addition to wild plants that are used for medicinal purposes. One fisherperson indicated that a permit is given by the Department of Wildlife and National Parks and costs roughly 200 pula (US\$35 at the time of fieldwork in 2011) for three years. During the interview, the man shared the logs he keeps of his daily catches that he turns in to the local office, explaining that this helps in getting future permits. He insisted that the fishing season takes place from March until December 31st and that there is no fishing in the intervening months. In addition to fishing permits, permits are needed to collect and sell reeds and grasses commercially but not for household use. There is a season for reed and grass collection that is advocated by local tribal authority officials working in coordination with the national government. Residents shared that they are informed by the chief and government to collect these materials in July and August after the "seeds have dropped." Other people talked about how the water needed to go down before reed collection could commence. One resident in Etsha 6 expressed displeasure with this, explaining that reeds are a natural product and people should be free to go where they want to collect them, noting that in the past she used to collect reeds and grasses whenever she wanted but now the national government has imposed rules limiting this access. Another resident in Etsha 6 emphasized the importance of having a mokoro to collect these materials. As she explained, the Bayei collect reeds and grasses in August, but with mekoros you can collect earlier, even in June. If you do not have a mokoro you need to wait for the water to go down, and then there might not be any reeds to collect by the time you arrive. This same informant explained that reed collection is a woman's responsibility and that women were taught when to collect. There would be meetings at the Kgotla (the traditional political center of the village) and then they would negotiate as a group for resource access. She noted that now people go to the meetings but they do not listen, and they collect when they want to.

One interview conducted with an Etsha 1 resident provides an example of how environmental change shapes livelihood decision-making. He was one of the residents in Etsha 13 displaced by the increased flooding that began in 2008, although it is worth noting that his move to Etsha 1 in that year was voluntary, done proactively before the waters destroyed the usefulness of his molapo field. This respondent was able to acquire rights from the Land Board to farm that same year, and was able to harvest enough thatch and reeds to make his new house and compound fencing. Unfortunately, at that time the rising waters had begun to affect floodplain lands further to the south, meaning that he lost much of his harvest in the next two years. Acquiring land rights outside of the secondary floodplain is apparently a longer process, one he had still not been able to complete, but that he was pursuing in order to have a less productive but non-floodable area to practice dryland farming of millet, maize, and sorghum. This respondent is an example of how local residents can be resourceful, using multiple strategies for growing crops, acquiring the thatch and reeds needed for building a new house compound, and proactively reducing losses while preparing for new opportunities. At the same time, he continued to face institutional constraints to acquiring new land that challenged his capacity to adapt his livelihood system to environmental variability.

Interviews in Etsha 13 revealed particularly strong views on the rules constraining livelihood flexibility. These views were intensified by the displacement of residents to the New Stands in the dryland area. One interview was completed with a family that was being encouraged by the government to move to the dryland area, because it was believed their house would likely be in the path of future floods. The male respondent explained that it will be difficult because no one in the household is working and they do not have enough money for a new plot. Previously, they had the money from the 1996 cattle eradication, but presently they did not have money to build new structures. When asked about resource collection, one family member explained that it was not possible to collect grass or reeds during early June and finish in July because the water level will not go down by that time. He explained that "if you go collect during July, you will get punished." When asked if the 
government will change the season because of changes to the water, he said that if they do, it will take a very long time. When asked if he thought the rules should change, he noted that "the government should not set rules on how we collect the reeds and grasses, especially the time for collection ... Maybe your house can burn in January, you have to wait to June. It makes it difficult to build houses."

\section{Conclusions}

This paper details the myriad ways in which variability, specifically of precipitation and flooding dynamics, in the study region of the Okavango Delta influences environmental perceptions and livelihood responses. Changes in environmental dynamics are challenging for residents because they reveal how adaptive responses are constrained due to rigidities within broader governance regimes. Residents in all three of the villages viewed precipitation as unpredictable and novel in a way that decreased the viability of farming, particularly within the drylands in the region. Flooding patterns were similarly difficult to predict, which most likely reflected the spatial variability of the flooding. Even with these dynamic environmental patterns, residents continue to rely upon a diverse set of natural resources and livelihood practices that are interlinked with biophysical dynamics. Attending to the interconnections and tensions between environmental change and livelihoods is much needed to understand the capacity of social and biophysical systems to respond to change. Residents within the Etsha villages experience and perceive environmental variability in precipitation and flooding in distinct ways that are related to residence location, while also being shaped by natural resource needs. The Etsha villages provide an illustration of how rigid livelihood systems can limit the ability of social actors to adapt to environmental changes. One example of this is the seasonality of reed collection that, while explained by governmental officials is intended to ensure sustainable extraction, constrains the ability of community members to collect materials at critical periods. Thus, even though the shifting flooding dynamics challenge the collection of reeds and thatch grasses, the rules for collection, including seasonality, are not as fluid as biophysical processes. In a similar way, agricultural production is directly impacted by variability in the extent, location, and duration of floodwaters, which results in uneven impacts for residents within the study region.

While scholarship on environmental governance and resilience often emphasizes social dynamics that allow for adaptation to environmental change, some studies underemphasize how these patterns are simultaneously produced by livelihood production systems, environmental perceptions, and biophysical processes. At a time of reported increasing climate variability, scholarship on environmental governance must attend not only to the rules that shape socio-environmental relationships but also environmental perceptions and the ways in which livelihood systems are able to respond. If livelihood systems remain rigid in response to biophysical change they will be unable to successfully adapt and may generate tensions with existing governance regimes. This has material import for the ways in which residents are able to access natural resources critical for livelihood production, in addition to land for molapo and dryland farming. Future scholarship and policy on climate change adaptation must attend to the ways in which institutional options for adaptation can be simultaneously produced by the dynamic and fluid interactions between social and ecological systems.

Acknowledgments: The research that informs this article was supported by the United States National Science Foundation (BCS/GSS-0964596) and BCS/GSS Research Experiences for Undergraduates (REU) Supplement Award. Support from the Frederick S. Pardee Center for the Study of the Longer-Range Future at Boston University helped the first author attend an environmental governance workshop that clarified many of the ideas in this paper. We are grateful to Fuata John, Japhet John, and Kentse Madise for their outstanding work as research assistants. Allison White and Evan Griffin were extremely helpful in conducting the interviews in 2011. We also thank Thomas Christiansen for making Figure 1. Finally, we appreciate the two anonymous reviewers and special issue editors whose feedback helped strengthen an earlier version of this manuscript.

Author Contributions: All four authors contributed to the research design and collection of data in the Etsha region in 2011. Brian King undertook the preparation of the manuscript with invaluable support from Jamie E. Shinn. Kelley A. Crews and Kenneth R. Young contributed to the writing of the paper and assisted with revisions during the review process.

Conflicts of Interest: The authors declare no conflict of interest. 


\section{References}

1. Solomon, S.; Qin, D.; Manning, M.; Chen, Z.; Marquis, M.; Averyt, K.B.; Tignor, M.; Miller, H.L., Jr. Climate Change 2007: The Physical Science Basis. Contribution of Working Group I to the Fourth Assessment Report of the IPCC; Cambridge University Press: Cambridge, UK; New York, NY, USA, 2007.

2. IPCC. Summary for Policymakers. In Climate Change 2013: The Physical Science Basis. Contribution of Working Group I to the Fifth Assessment Report of the Intergovernmental Panel on Climate Change; Stocker, T.F., Qin, D., Plattner, G.-K., Tignor, M., Allen, S.K., Boschung, J., Nauels, A., Xia, Y., Bex, V., Midgley, P.M., Eds.; Cambridge University Press: Cambridge, UK; New York, NY, USA, 2013; pp. 3-29.

3. Niang, I.; Ruppel, O.C.; Abdrabo, M.A.; Essel, A.; Lennard, C.; Padgham, J.; Urquhart, P. Africa. In Climate Change 2014: Impacts, Adaptation, and Vulnerability. Part B: Regional Aspects. Contribution of Working Group II to the Fifth Assessment Report of the Intergovernmental Panel on Climate Change; Barros, V.R., Field, C.B., Dokken, D.J., Mastrandrea, M.D., Mach, K.J., Bilir, T.E., Chatterjee, M., Ebi, K.L., Estrada, Y.O., Genova, R.C., et al., Eds.; Cambridge University Press: Cambridge, UK; New York, NY, USA, 2014; Chapter 22; pp. 1199-1266.

4. Murray-Hudson, M.; Wolski, P.; Ringrose, S. Scenarios of the impact of local and upstream changes in climate and water use on hydro-ecology in the Okavango Delta, Botswana. J. Hydrol. 2006, 331, 73-84. [CrossRef]

5. Ostrom, E. Frameworks and theories of environmental change. Glob. Environ. Change 2008, 18, $249-252$. [CrossRef]

6. Ostrom, E. A general framework for analyzing sustainability of social-ecological systems. Science 2009, 325, 419-422. [CrossRef] [PubMed]

7. Slovic, P.; Finucane, M.L.; Peters, E.; MacGregor, D.G. Risk as analysis and risk as feelings: Some thoughts about affect, reason, risk, and rationality. Risk Anal. 2004, 24, 311-322. [CrossRef] [PubMed]

8. Marx, S.M.; Weber, E.U.; Orlove, B.S.; Leiserowitz, A.; Krantz, D.H.; Roncoli, C.; Phillips, J. Communication and mental processes: Experiential and analytic processing of uncertain climate information. Glob. Environ. Change 2007, 17, 47-58. [CrossRef]

9. Roncoli, C.; Ingram, K.; Kirshen, P. Reading the rains: Local knowledge and rainfall forecasting in Burkina Faso. Soc. Nat. Resour. 2002, 15, 409-427. [CrossRef]

10. Valdivia, C.; Seth, A.; Gilles, J.L.; García, M.; Jiménez, E.; Cusicanqui, J.; Navia, F.; Yucra, E. Adapting to climate change in Andean ecosystems: Landscapes, capitals, and perceptions shaping rural livelihood strategies and linking knowledge systems. Ann. Assoc. Am. Geogr. 2010, 100, 818-834. [CrossRef]

11. Ovuka, M.; Lindqvist, S. Rainfall variability in Murang'a District, Kenya: Meteorological data and farmers' perception. Geogr. Ann.: Ser. A Physic. Geogr. 2000, 82, 107-119. [CrossRef]

12. Gamble, D.W.; Campbell, D.; Allen, T.L.; Barker, D.; Curtis, S.; McGregor, D.; Popke, J. Climate change, drought, and Jamaican agriculture: Local knowledge and the climate record. Ann. Assoc. Am. Geogr. 2010, 100, 880-893. [CrossRef]

13. Dahlberg, A.C. Vegetation diversity and change in relation to land use, soil and rainfall—A case study from North-East District, Botswana. J. Arid Environ. 2000, 44, 19-40. [CrossRef]

14. Meze-Hausken, E. Contrasting climate variability and meteorological drought with perceived drought and climate change in northern Ethiopia. Clim. Res. 2004, 27, 19-31. [CrossRef]

15. Vedwan, N. Culture, climate and the environment: Local knowledge and perception of climate change among apple growers in Northwestern India. J. Ecol. Anthropol. 2006, 10, 4-18. [CrossRef]

16. Turner, M.D. Political ecology I: An alliance with resilience? Prog. Hum. Geogr. 2014, 4, 616-623. [CrossRef]

17. Ostrom, E. Governing the Commons: The Evolution of Institutions for Collective Action; Cambridge University Press: New York, NY, USA, 1990.

18. Folke, C.; Hahn, T.; Olsson, P.; Norberg, J. Adaptive governance of social-ecological systems. Annu. Rev. Environ. Resour. 2005, 30, 441-473. [CrossRef]

19. Lemos, M.C.; Agrawal, A. Environmental governance. Ann. Rev. Environ. Resour. 2006, 31, 297-325. [CrossRef]

20. Young, O.R. Effectiveness of international environmental regimes: Existing knowledge, cutting-edge themes, and research strategies. Proc. Natl. Acad. Sci. USA 2011, 108, 19853-19860. [CrossRef] [PubMed]

21. Nelson, D.R.; Adger, W.N.; Brown, K. Adaptation to environmental change: Contributions of a resiliency framework. Ann. Rev. Environ. Resour. 2007, 32, 395-419. [CrossRef] 
22. Moss, R.H.; Meehl, G.A.; Lemos, M.C.; Smith, J.B.; Arnold, J.R.; Arnott, J.C.; Behar, D.; Brasseur, G.P.; Broomell, S.B.; Busalacchi, A.J.; et al. Hell and high water: Practice-relevant adaptation science. Science 2013, 342, 696-698. [CrossRef] [PubMed]

23. Pahl-Wostl, C. A conceptual framework for analyzing adaptive capacity and multi-level learning processes in resource governance regimes. Glob. Environ. Change 2009, 19, 354-365. [CrossRef]

24. Heinl, M.; Neuenschwander, A.; Sliva, J.; Vanderpost, C. Interactions between fire and flooding in a southern African floodplain system (Okavango Delta, Botswana). Landsc. Ecol. 2006, 21, 699-709. [CrossRef]

25. Gumbricht, T.; McCarthy, T.S.; Merry, C.L. The topography of the Okavango Delta, Botswana, and its tectonic and sedimentological implications. S. Afr. J. Geol. 2001, 104, 243-264. [CrossRef]

26. Neuenschwander, A.L.; Crews, K.A. Disturbance, management, and landscape dynamics: Wavelet analysis of vegetation indices in the lower Okavango Delta. Photogramm. Eng. Remote Sens. 2008, 74, 753-764. [CrossRef]

27. Ellery, W.N.; Dahlberg, A.C.; Strydom, R.; Neal, M.J.; Jackson, J. Diversion of water flow from a floodplain wetland stream: an analysis of geomorphological setting and hydrological and ecological consequences. J. Environ. Manag. 2003, 68, 51-71. [CrossRef]

28. McCarthy, T.S.; Cooper, G.R.J.; Tyson, P.D.; Ellery, W.N. Seasonal flooding in the Okavango Delta, Botswana-Recent history and future prospects. S. Afr. J. Sci. 2000, 96, 25-33.

29. Wolski, P.; Todd, M.C.; Murray-Hudson, M.A.; Tadross, M. Multidecadal variability in hydro-climate of Okavango river system, southwest Africa, in the past and under changing climate. J. Hydrol. 2012, 475, 294-305. [CrossRef]

30. CSO (Botswana Central Statistics Office). Botswana Population and Housing Census; Central Statistics Office: Gabarone, Botswana, 2011.

31. Kgathi, D.L.; Mmopelwa, G.; Mosepele, K. Natural resources assessment in the Okavango Delta, Botswana: Case studies of some key resources. Nat. Resour. Forum 2005, 29, 70-81. [CrossRef]

32. Mbaiwa, J.E.; Darkoh, M.B.K. Sustainable development and natural resource competition and conflicts in the Okavango Delta. Botsw. Notes Rec. 2005, 37, 40-60.

33. Motsholapheko, M.R.; Kgathi, D.L.; Vanderpost, C. Rural livelihoods and household adaptation to extreme flooding in the Okavango Delta, Botswana. Phys. Chem. Earth Parts A/B/C 2011, 36, 984-995. [CrossRef]

34. Kgathi, D.L.; Ngwenya, B.N.; Wilk, J. Shocks and rural livelihoods in the Okavango Delta, Botswana. Dev. S. Afr. 2007, 24, 289-308. [CrossRef]

35. King, B. Spatialising livelihoods: Resource access and livelihood spaces in South Africa. Trans. Inst. Br. Geogr. 2011, 36, 297-313. [CrossRef]

36. Meyer, T.; Bendsen, H. The dynamics of land use systems in Ngamiland: Changing livelihood options and strategies. In Environmental Monitoring of Tropical and Subtropical Wetlands; Bernard, T., Mosepele, K., Ramberg, L., Eds.; HOORC Report Series No. 1; HOORC: Maun, Botswana, 2003; pp. 278-307.

37. Magole, L.; Thapelo, K. The impact of extreme flooding of the Okavango River on the livelihood of the molapo farming community of Tubu village, Ngamiland Sub-district, Botswana. Botsw. Notes Rec. 2005, 37, 125-137.

38. Mbaiwa, J.E.; Ngwenya, B.N.; Kgathi, D.L. Contending with unequal and privileged access to natural resources and land in the Okavango Delta, Botswana. Singap. J. Trop. Geogr. 2008, 29, 155-172. [CrossRef]

39. Mosepele, K. Preliminary Description of the Okavango Delta fishery; Unpublished technical report. Fisheries Section, Ministry of Agriculture: Gaborone, Botswana, 2001.

40. Wolski, P. Okavango Delta Monitoring and Forecasting. 2014. Available online: http:/ /okavangodata.ub. bw/ori/monitoring/rainfall/\# (accessed on 3 September 2014).

41. Shinn, J.E.; King, B.; Young, K.R.; Crews, K.A. Variable adaptations: Micro-politics of environmental displacement in the Okavango Delta, Botswana. Geoforum 2014, 57, 21-29. [CrossRef]

(c) 2016 by the authors; licensee MDPI, Basel, Switzerland. This article is an open access article distributed under the terms and conditions of the Creative Commons Attribution (CC-BY) license (http://creativecommons.org/licenses/by/4.0/). 